\title{
Growing food and building power: Urban agriculture in New York City
}

Review by Wende Marshall *

Temple University

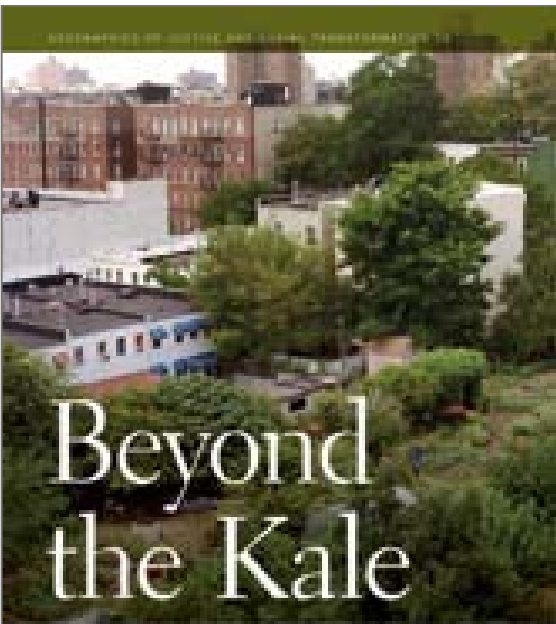

Review of Beyond the Kale: Urban Agriculture and Social Justice Activism in New York City, by Kristin Reynolds and Nevin Cohen. (2016). Published by University of Georgia Press. Available as hardcover, paperback, and ebook; 224 pages. Publisher's website: http://www.ugapress.org/index.php/books/beyond the kale

$\mathrm{T}$ he early $20^{\text {th }}$-century Italian social theorist and revolutionary, Antonio Gramsci, argued that in struggling for socialism, the working class pursued two strategies. The crucial, decisive clash, the frontal attack between workers and the state, Gramsci characterized as the "war of maneuver." In contrast, he characterized the "war of position" as struggles in civil society in which the working

\footnotetext{
* Wende Marshall is a community organizer in North Philadelphia and an adjunct teacher in the Intellectual Heritage Program at Temple University. She can be contacted at wendentia@gmail.com.
}

class organizes itself and works to gain power and influence.

In many ways, Kristin Reynolds' and Nevin Cohen's Beyond the Kale, an analysis of the grassroots urban farming and gardening movement in New York City, describes the movement as a "war of position." Urban gardening, in the analysis of the authors and many of their informants, is not just about growing food, but also about defining and defying the deeper structures of oppression in a race- and class-based society, and about achieving environmental justice and liberation. While for many farms and gardens the point is simply to 
grow nutritional food, Reynolds and Cohen focus on the activists for whom growing food is a starting point to dismantle oppression "at its core" (p. 14).

Although much of the media conversation about urban gardening focuses on the activities of young, white, middle-class people seeking to access nutritious food and promote a kind of environmentalism, Reynolds and Cohen focus on the successful urban farming efforts led by workingclass people of color, including immigrants from the Global South. Through the authors' in-depth interviews with farmers and gardeners and their participant-observation, the story of a multifaceted survival strategy centered on the growing of food emerges. Unlike white, middle-class-led projects, which are centered on vague notions of social justice and the imperative of building sustainable cities, many of the farmers and gardeners profiled in the book understand their work as a form of political expression contesting neoliberal capitalism and the privatization of urban space. According to the authors, some urban farmers resist food insecurity, reclaim cultural roots, foster a sense of self-determination, and "respond to the latent crisis of discrimination and government abandonment" in poor neighborhoods (p. 13). Robert and De Vanie Jackson, who run a Christian-based farm in Brooklyn, "see the food system disparities that affect African American communities as a consequence of systematic economic disenfranchisement," and describe urban agriculture as "the starting point for a self-reliance movement" (pp. 40-41).

The historical roots of the urban agricultural movement described in Beyond the Kale stem from the 1960s and 1970s when grassroots-led community gardening emerged as a response to interconnected economic and political trends that were devastating working-class communities of color. Neoliberal fiscal austerity (for example, reductions in funding for education, health care, parks, policing, sanitation, and fire-protection services) resulted in the rampant disinvestment in wide swaths of the city beset by crumbling buildings and vacant lots. Many of the gardens and farms portrayed in the book are on lots created "by this period of malignant government and property- owner neglect of low income communities of color" (p. 28).

In Reynolds' and Cohen's analysis, the commitment of New York City farmers and gardeners to intersectional justice goes beyond simply growing food. The assertion of agency in the face of disenfranchisement and the attempt to practice self-determination are critical aspects of the movement. Farmers and gardeners engage in challenging policy by reframing problems to include structural causes of food, health, and environmental inequities. They build coalitions across race and nation, highlighting structural poverty and linking struggles against racism, sexism, and heterosexism. The authors also describe the incredible obstacles that farmers and gardeners face, from unstable land tenure to the lack of resources, time, and privilege-obstacles that loom particularly large for those engaged in the most radical work. Thus, organizations that are focused on achieving social justice "often face numerous challenges that are rooted in, and made more formidable by, the very structural forms of oppression that their programs are intended to address" (p. 112).

What is exciting and original about the book is the authors' emphasis on the ways in which the movement's practitioners challenge ruling ideas about class hierarchy, cultural difference, and the commodification of food and land, while reinvigorating the meaning of participatory democracy. It is the conceptual frameworks and theories of change that are put into practice in the New York City urban farming and gardening movement that most exemplify the Gramscian notion of a "war of position." For Gramsci, the war of position meant the development of new ideologies and practices, new ways of thinking and being, and revitalized conceptions of the world that make the "governed intellectually independent of the governing, in order to destroy one hegemony and create another" (Gramsci \& Forgacs, 2000, p. 98).

The book's major weakness is its lack of attention to the deep economic, environmental, health, and racial crises that characterize the current moment and the political terrain through which urban gardening and farming is occurring at this point in the $21^{\text {st }}$ century. These multiple crises signal both an erosion of ruling-class authority and 
existential threats to the entire planet. Without placing the movement in an analytic frame that considers these profound crisis, the urban farming and gardening movement's full potential as a major contributor to the creation of a world based on justice and the interrelation of humans and nature is understated.

Nevertheless, Beyond the Kale is a compelling analysis of New York City's urban farming and gardening movement, and an inspiring tale of activists engaged in growing "freedom and possibility" in some areas struggling the hardest with the effects of neoliberal disenfranchisement.

\section{Reference}

Gramsci, A. (Author), \& Forgacs, D. (Ed.). (2000). The Antonio Gramsci Reader: Selected Writings 1916-1935. New York: New York University Press. 